5. Самойленко А. Диалог как музыкально-культурологический феномен: методологические аспекты современного музыкознания: дис. ... доктора искусствоведения. 17.00.03. Одесса, 2003. 437 с.

6. Самойленко А. Музыковедение и методология гуманитарного знания. Проблема диалога: Монография. Одесса : Астропринт, 2002. 244 с.

7. Флоренский П. Из богословского наследия // Богословские труды. Москва, 1972. Вып. 9. С. 85-248.

8. Флоренский П. Философия культа. Москва : Мысль, 2004. 685 с.

9. Флоренский П., свящ. Стоп и утверждение истины: Опыт православной теодицеи. Москва : ООО Издательство АСТ, 2003. 640 с.

\title{
References
}

1. Averintsev, S. (2004) The poetics of early Byzantine literature. S.-P. : Classical alphabet [in Russian].

2. Berdyaev, N. (1998) Eternity and time. Bulletin of the RHD. Paris -New York - Moscow [in Russian].

3. Lotman, Yu. (2001) Inside the thinking worlds. The Semiosphere. S.-Pb.: Art-SPB [in Russian].

4. Osadchaya, S. (2012) Theoretical aspects of studying the Orthodox singing tradition: history and modernity: [monograph]. Odessa: Astroprint [in Russian].

5. Samoylenko, A. (2003) Dialogue as a musical and cultural phenomenon: the methodological aspects of modern musicology. Doctor's thesis. Odessa. [in Russian].

6. Samoylenko, A. (2002) Musicology and methodology of humanitarian knowledge. The problem of dialogue: Monograph. Odessa: Astroprint [in Russian].

7. Florensky, P. (1972) From the theological heritage. Theological works. Moscow, 9 [in Russian].

8. Florensky, P. (2004) Philosophy of the cult. Moscow : Thought [in Russian].

9. Florensky, P. (2003) Stop and the affirmation of the truth: The experience of Orthodox theodicy. Moscow: OOO AST Publishing House [in Russian].

Стаття надійшла до редакції 28.08.2018 p.

Удк $378.011 .3-051: 7$

\author{
Savchenko Regina \\ doctor of pedagogical sciences, professor, \\ professor of the department of theory \\ and methodology of music education, choral singing and \\ conducting of the \\ National Pedagogical University behalf of M.P. Dragomanova \\ ORCID 000243808777 \\ sarina_30@ukr.net
}

\section{CULTURALITY OF MUSIC-PEDAGOGICAL TRAINING OF FUTURE SPECIALISTS ARTISTIC EDUCATION}

Objective. Substantiation of expediency of realization of the cultural approach in musical and pedagogical preparation of the future experts of art education. The methodology of the research consists in the study of the culturological approach in relation to the musical and pedagogical preparation of students - future specialists in the field of art education. This methodological approach allows us to disclose and analyze certain aspects and components of vocational training of future music teachers in social relations, to find a dynamic view of the future of man, new dimensions of his self-realization. Scientific novelty of the work is to expand the understanding of the possibilities of culturological impact in the musical and pedagogical preparation of students: an awareness of the potential of the culturological approach in the educational process; enriching the cultural space of students; the realization of the principle of cultural appropriateness as a sign of artistic education; as means of formation and development of student culture: universal, pedagogical, artistic. Conclusions. The culturological approach provides a methodological basis for the professional training of future specialists in art education, namely: on the affirmation of universal human values, value-semantic accents of activity; the fundamental provisions of normative documents concerning the cultural appropriateness of musical and pedagogical activity, the unity of universal and national, public and personal, theoretical and practical, education and upbringing.

Keywords: culturological approach, musical and pedagogical training, future specialists of art education.

Савченко Регіна Анатоліївна, доктор педагогічних наук, профессор, профресор кафедри теорії та методики музичної освіти, хорового співу і диригування Національного педагогічного університету імені М. П. Драгоманова

Культуровідповідність музично-педагогічної підготовки майбутніх фахівців мистецької освіти

Мета роботи. Обгрунтування доцільності реалізації культурологічного підходу в музично-педагогічної підготовки майбутніх фахівців художньої освіти. Методологія дослідження полягає в дослідженні культурологічного підходу стосовно музично-педагогічної підготовки студентів - майбутніх фрахівців в галузі мистецької освіти. Зазначений методологічний підхід дозволяє розкрити і піддати аналізу певні аспекти і компоненти професійної підготовки майбутніх педагогів-музикантів у соціальних відносинах, знайти динамічний погляд на майбутнє людини, нові виміри його самореалізації. Наукова новизна роботи полягає в розширенні уявлень про можливості культурологічного впливу в музично-педагогічної підготовки студентів: усвідомленням потенціалу культурологічного під-

(c) Savchenko R., 2018 
ходу в освітньому процесі; збагаченням культурного простору студентів; реалізацією принципу культуровідповідності як ознаки художньої освіти; як засобу формування і розвитку культури студента: загальнолюдської, педагогічної, художньої. Висновки. Культурологічний підхід забезпечує методологічну основу професійної підготовки майбутніх фахівців художньої освіти, а саме: за твердженням загальнолюдських цінностей, ціннісно-смислових акцентів діяльності; принципових положень нормативних документів, що стосуються культуровідповідності музично-педагогічної діяльності, єдності загальнолюдського і національного, громадського та особистого, теоретичного і практичного, навчання і виховання.

Ключові слова: культурологічний підхід, музично-педагогічна підготовка, майбутні фрахівці художньої освіти.

Савченко Регина Анатольевна, доктор педагогических наук, профресор, професор кафедры теории и методики музыкального образования, хорового пения и дирижирования Национального педагогического университета имени М.П. Драгоманова

Культуросообразность музыкально-педагогической подготовки будущих специалистов художественного образования

Цель работы. Обоснование целесообразности реализации культурологического подхода в музыкальнопедагогической подготовке будущих специалистов художественного образования. Методология исследования заключается в исследовании культурологического подхода применительно к музыкально-педагогической подготовке студентов - будущих специалистов в области художественного образования. Указанный методологический подход позволяет раскрыть и подвергнуть анализу определенные аспекты и компоненты профессиональной подготовки будущих педагогов-музыкантов в социальных отношениях, найти динамичный взгляд на будущее человека, новые измерения его самореализации. Научная новизна работы заключается в расширении представлений о возможностях культурологического воздействия в музыкально-педагогической подготовке студентов: осознанием потенциала культурологического подхода в образовательном процессе; обогащением культурного пространства студентов; реализацией принципа культуросообразности как признака художественного образования; как средства формирования и развития культуры студента: общечеловеческой, педагогической, художественной. Выводы. Культурологический подход обеспечивает методологическую основу профессиональной подготовки будущих специалистов художественного образования, а именно: по утверждению общечеловеческих ценностей, ценностно-смысловых акцентов деятельности; принципиальным положениям нормативных документов, касающихся культуросообразности музыкально-педагогической деятельности, единства общечеловеческого и национального, общественного и личностного, теоретического и практического, обучения и воспитания.

Ключевые слова: культурологический подход, музыкально-педагогическая подготовка, будущие специалисты художественного образования.

Relevance of the research topic. Political, social, and economic events in Ukraine have determined the priority of the European vector of development and, accordingly, oriented the education to enter the European educational space, in which the tendency of the humanitarization of education is traced. In the context of this direction, attention is focused on the geopolitical problems of the society: personal freedom, personal, national, cultural, state values, etc. These positions have to a certain extent been reflected in the modern educational space, in domestic cultural studies, in which pedagogy plays an important role. In the context of solving this problem, the issue of the cultural nature of the professional, in particular, musical and pedagogical training of future art education specialists, acquires urgency.

Analysis of research and publications. The review of modern philosophical and psychologicalpedagogical literature gives grounds to state the strengthening of the ties between education and culture, the constant growth of attention to the culturological problems of education and upbringing (N.Alekseev, Sh. Amonashvili, A. Asmolov, G. Ball, E. Bondarevskaya, A. Valitskaya, A. Gazman, V. Zinchenko, I. Zyazyun, V. Kremen, S. Kulnevich, M. Kultaeva, V. Serikov, V. Slastenin, E. Shiyanov, and Yakimanskaya et al.). This is the culturological approach that provides a panoramic multidimensional view and a polysystemic explanation of the essence of cultural problems, values and components of modern education. the development of man himself and his emergence as a person.

Purpose of the study. Substantiation of expediency of realization of the cultural approach in musical and pedagogical preparation of the future experts of art education.

Statement of the main material. L. White, who is considered the father of culturology, singled out three of its components, namely: a technological subsystem that includes material devices for communicating with nature; a social subsystem that provides for ways and types of behavior in society; an ideological subsystem consisting of ideas, images and beliefs. Each of them can be explored as a cultural phenomenon. The scientist also stressed that the research and cognitive potential of culture is of particular importance for the study of man and society, since it is the basis of the sciences. Social communication is only a function of culture, its derivative, and therefore sociology depends on culturology, like other sciences about man [6, 2223]. The culturological approach is conditioned by the objective connection of man with culture as a system of values: man includes a part of culture; it not only develops on the basis of the culture that it has learned, but also replenishes it with new elements. In this regard, the assimilation of culture is the development of man himself and his emergence as a person.

Culturology complements pedagogy, which develops for students methods of translating fundamental knowledge and relevant samples of cultural competence, and culturology forms the most general structure and content of that cultural competence, which is broadcast by means of pedagogy [4, 92-93]. Under the 
culturological approach to the training of art education specialists, we mean a set of theoretical and methodological provisions and organizational and pedagogical measures aimed at creating conditions for the mastering and translation of artistic and pedagogical values and technologies that ensure the professional self-realization of the individual within a particular epoch and culture.

The cultural direction of the educational process of art education specialists is one of the components of the new education paradigm that will enrich its cultural space, orient itself to independent mastering of world outlook bases, awareness of one's own destiny in the modern sociocultural space.

Cultural approach allows us to consider the management of pedagogical phenomena on a broad background, provides for the study of general laws of the development of the culture of the individual and society, the principles of their functioning, interrelation and interdependence. This involves creating conditions for self-determination of the future teacher's personality in the environment, representing a certain harmonious integrity of the culture of knowledge and thinking, creative action, feelings, communication and behavior embodied in the forms of individual experience. The potential of the cultural approach in the educational process of the future teachers of artistic disciplines is as follows:

- election to achieve the purpose and objectives of the study of an adequate definition of culture;

- consideration of processes and phenomena as cultural phenomena;

- use of essential features of culture, its substantial elements, axiological, functional, instrumental and other possibilities;

- knowledge and use of theoretical achievements of cultural studies and its main components: historical, fundamental, applied cultural studies, anthropology [5].

So, the culturological approach regards the phenomenon of culture as the core of human understanding, its consciousness and life activity, and culture-creation. Such a humanistic position recognizes a person as a subject of culture, its main actor.

Cultural approach will enrich the cultural space of the student, focus on self-mastery of world outlook, awareness of one's own destiny in the modern socio-cultural space, will direct to creating conditions for mastering and translating artistic and pedagogical values and technologies that ensure professional selfrealization of the individual within a particular era and culture.

The principle of cultural appropriateness presupposes such a meaningful filling of the educational process, as a result of which the musical art is perceived by students as a cultural value, as an asset of the development of world culture. Cultural appropriateness as a necessary sign of art education in modern conditions is oriented towards students' understanding of art as a social phenomenon, to comprehend the significance of artistic culture in the surrounding being, to highlight the social functions of artistic activity.

The principle of cultural appropriateness also reaches the interpretation of art education as a means of forming and developing the student's culture as a pedagogical reality, conditioned by the objective connection of man with culture as a system of values. Man contains a part of culture, develops on its basis and replenishes it with new elements, in this connection, the assimilation of culture is the development of man himself and his emergence as a person. Art education will not be complete, it will not achieve its goal unless it provides for the development of a culture of the individual. Clear ideas about the specific possibilities of art in various spheres of social development will help students find out the meaning of the personal artistic formation of his culturological foundations, the role of a developed personal culture in his own life. The productivity of the support for the principle of cultural appropriateness in the teaching of art is evidenced by the measure of personal development of the artistic culture of society.

In the implementation of this principle, the formation of students' ability to Ukrainian cultural identification and interiorization of values, the choice and implementation of a culturally appropriate way of life, behavior, self-determination becomes important. The object of cultural self-identification and self-determination of the future specialist of art education is the Ukrainian national culture, therefore, the cultural appropriateness of his upbringing consists of universal universal, national and regional values. This orientation of the pedagogical process is important for the preparation of future music teachers.

The principle of cultural appropriateness presupposes an inseparable relationship of upbringing with the cultural achievements of mankind and, in particular, of its people. At the philosophical level, the conceptual load of the term "culture" reflects the system of people's views on nature and society; at the masshousehold level expresses the inherited and cultivated in the people's love for everything native (language, culture, traditions, etc.); on the rational-social level determines the being of the people in time, the awareness and self-affirmation of themselves as an ethnos among other nations of the world and cooperation with them; on a personal level - professes a sense of love and responsibility, prefers the interests of society own.

The deep reform of modern education and upbringing is based on national educational traditions of the Ukrainian and classical European cultural heritage, popular pedagogy. Philosophy considers professional culture as a moral and political principle, a social feeling whose content is love and devotion to the fatherland, pride in its past and present. Moral value is determined by the fact that it is one of the forms of subordination of personal and public interests, the unity of man and society.

I. Bekh [2] considers the formation of professional culture as a fundamental personal value. Il'in [3] interprets the notion of professional culture as its manifestation in social relations, as the ability of the indi- 
vidual not only to respect his ethnos, but also to treat other peoples with respect. That is, it is about affirming universal human values as determining factors of professional culture.

The structure of professional culture consists of a system of components, each of which combines cognitive, emotional-volitional and behavioral components, namely:

- consciousness (self-consciousness) as a result of the individual's comprehension of his civic role in society (protection of historical, cultural, political, economic achievements, independence, personal contribution to the development of Ukraine's statehood, enrichment with professional knowledge, exemplary civil behavior, etc.);

- feelings (love for one's native land, language, culture, respect for the historical past, care, responsibility, loyalty to the national idea, tolerance, etc.);

- behavior and activities (fulfillment of civil duties, observance of the Constitution of Ukraine, universal and national moral ideals, honoring of national traditions, respect for the national dignity of other peoples, tolerance, etc.) [2].

So, the content of professional culture is considered as a moral quality and value reference, a complex phenomenon of the spiritual life of a person and society, which is reflected in the personal and public consciousness, uniting them and acting as a decisive factor in the future specialist's understanding of universal values.

Pedagogical culture is a part of universal culture. It embodies the spiritual values of education and upbringing (pedagogical knowledge, theories, concepts, accumulated pedagogical experience, professional ethical norms) and material (means of teaching and upbringing), as well as the ways of creative pedagogical activity that serve the socialization of the individual in specific historical conditions. The main structural components of pedagogical culture are: pedagogical values, creative methods of pedagogical activity, the experience of creating by the teacher models of pedagogical practice from the standpoint of humanism. Indicators of a high level of development of pedagogical culture consider the humanistic orientation of the teacher's personality; psychological and pedagogical competence and developed pedagogical thinking; education in the field of the subject, possession of pedagogical technologies; the experience of creative activity, the ability to substantiate their own pedagogical activity as a system (didactic, educational, methodical) culture of professional conduct (pedagogical communication, language, appearance).

The most important component of culture as a totality of values created by humanity is the artistic culture uniting all kinds of art, the process of artistic creativity, its results and the system of measures for the creation, preservation and dissemination of artistic values, the education of creative cadres and the audience. The core of artistic culture is art as an artistic and imaginative reproduction of the present and imaginary, as one of the most important factors of the spiritual life of mankind. Aesthetics is a system of laws, concepts and categories that reflect the aesthetic qualities of reality and the process of mastering it according to the laws of beauty, the features of the functioning of art, its perception and understanding of its results. Studying the general laws of the development of art, aesthetics is a general theoretical basis for special sciences, which are mainly applied in nature (literary criticism, theater studies, musicology, the theory of fine arts, etc.).

Musical art occupies a unique place in the spiritual life of society due to its polyfunctionality. Almost each of the functions of art is an understudy of one or another form of practical human activity: there is a science whose purpose is to study and to know the surrounding world, but art is also cognition, a means of education; there is a language and modern means of communication, art is a special language and means of information.

Among the many functions of art (socially transforming, cognitive-heuristic, artistic-conceptual, prediction, information and communicative, educational, suggestion, aesthetic, hedonistic), the most important in the context of the problem under consideration is the educational (formation of a complete personality) and aesthetic (the formation of value orientations).

Musical art affects the mind and soul of a person comprehensively, forming an integral personality. The impact on the personality is influenced by the aesthetic ideal, which manifests itself in both positive and negative images; which allows a person to experience other lives as their own and enrich themselves with other people's experience (educational). Under the influence of musical art, aesthetic tastes are formed, the creative origin of the personality awakens, and its desire to create according to the laws of beauty (aesthetic function). This orientation of the pedagogical process is important for the professional training of future specialists in art education.

Since the intonational approach is one of the main principles in the formation of the folk personality thesaurus, the musical and pedagogical process should be based on the works of Ukrainian folk music in order to master the figurative system, melody, harmony, rhythm, which is achieved on the basis of systematic intonational listening in the process of perception and playing music. Penetration into the intonationalimage essence of ethno-musical traditions allows us to comprehend the essence of the national mentality and the main tendency of the Ukrainian artistic consciousness, which combines high emotionality, sensitivity, lyricism. This trend can be overcome on the basis of identifying the optimal ratio of pedagogical means that promote preservation and artistic uniqueness, and artistic normativity in the artistic and creative orientations of students. Full-fledged artistic development does not occur by overcoming "one-sided" hobbies and artistic passions in art, not by leveling their individuality, but, on the contrary, on the basis of consolidating these 
advantages. Actualization of the individual, reliance on the individual principle makes it possible to "pull up" to the highest level of development all the components of the musical and pedagogical preparedness of future teachers.

Scientific novelty of the work is to expand the understanding of the possibilities of culturological impact in the musical and pedagogical preparation of students: an awareness of the potential of the culturological approach in the educational process; enriching the cultural space of students; the realization of the principle of cultural appropriateness as a sign of artistic education; as means of formation and development of student culture: universal, pedagogical, artistic.

Conclusions. The culturological approach provides a methodological basis for the musical and pedagogical training of future art education specialists, namely: on the affirmation of universal human values, the value-semantic emphasis of activity; the fundamental provisions of normative documents concerning the cultural appropriateness of musical and pedagogical activity, the unity of universal and national, public and personal, theoretical and practical, education and upbringing.

\section{תimepamypa}

1. Балл Г.О., Мєдінцев В.О. Особистість як індивідуальний модус культури і як інтегративна якість особи. Горизонти освіти. 2011. № 3. С. 7-14.

2. Бех І.Д. Виховання особистості: У 2 кн. Кн. 2: Особистісно -орієнтований підхід: науково-практичні засади: Навч.-метод посібник. К.: Либідь, 2003. 344 с.

3. Ильин И.А. Основы Христианской Культуры. Издание Братства Преп. Иова Почаевского. Мюнхен 1990.

4. Социология молодежи. Под ред. проф. В. Т. Лисовского. СПб. Изд-во С. - Петербургского университета. $1996.460 \mathrm{c}$.

$448 \mathrm{c}$.

5. Кремень В.Г. Освіта і наука в Україні - інноваційні аспекти. Стратегія. Реалізація. К. Грамота. 2005.

6. Култаєва М. Культурологічний поворот у філософії освіти: теоретико-методологічні можливості та практичні перспективи. Філософія освіти. 2012. № 1-2 (11). С. 147 - 163.

7. Уайт Л. Избранное: Эволюция культуры. Москва. РОССпЭН. 2004. 1064 с.

8. Якиманская И.С. Технология личностно - ориентированного образования. М. 2000. 96с.

\section{References}

1. Ball H.O.(2011). Miedintsev V.O. Osobystist yak indyvidualnyi modus kultury i yak intehratyvna yakist osoby. Horyzonty osvity. № 3. S. 7-14 [in Ukrainian].

2. Bekh I.D.( 2003). Vykhovannia osobystosti: U 2 kn. Kn. 2: Osobystisno oriientovanyi pidkhid: naukovopraktychni zasady: Navch.-metod. Posibnyk Kyiv: Lybid [in Ukrainian]. [in Germanic].

3. Ylyn Y.A. (1996). Osnovы Khrystyanskoi Kulturb.Yzdanye Bratstva Prep. Yova Pochaevskoho. Miunkhen

4. Sotsyolohyia molodezhy / Pod red. prof. V. T. Lysovskoho. SPb.: Yzd-vo

S. - Peterburhskoho unyversyteta [in Russian] [in Ukrainian].

5. Kremen V.H.(2005). Osvita i nauka v Ukraini - innovatsiini aspekty. Stratehiia. Realizatsiia. Kyiv: Hramota.

6. Kultaieva M. ( 2012). Kulturolohichnyi povorot u filosofii osvity: teoretyko-metodolohichni mozhlyvosti ta praktychni perspektyvy Filosofiia osvity. № 1-2 (11). S. 147 - 163. [in Ukrainian].

7. Uait L.(2004). Yzbrannoe: Эvoliutsyia kulturb. Moskva: ROSSPЭN [in Russian].

8. Yakymanskaia Y.S.(2000). Tekhnolohyia lychnostno - oryentyrovannoho obrazovanyia. Moskva [in Russian].

Стаття надійшла до редакції 09.08.2018 p. 